\title{
VALUE PROPOSITION: APPLICATION OF VALUE CREATION ACTIVITIES MODEL IN THE SUPERMARKET (VCAM-S)
}

\author{
PAULO R. CONDI ${ }^{1}$ \\ (iD) https://orcid.org/0000-0002-9507-8307 \\ DARIO DE O. LIMA-FILHO \\ (iD) https://orcid.org/0000-0002-9179-7670 \\ CAROLINE P. S. FINOCCHIO \\ (iD) https://orcid.org/0000-0002-0979-4594 \\ FILIPE QUEVEDO-SILVA ${ }^{2}$ \\ (iD) https://orcid.org/0000-0001-7494-4651
}

To cite this paper: Condi, P. R., Lima-Filho, D. O., Finocchio, C. P. S., \& Quevedo-Silva, F. (2018). Value proposition: Application of value creation activities model in the supermarket (VCAM-S). Revista de Administração Mackenzie, 19(4). doi:10.1590/1678-6971/eRAMR180028

Submission: Mar. 09, 2018. Acceptance: May. 15, 2018.

1 Universidade Anhanguera, São Paulo, SP, Brazil.

2 Universidade Federal de Mato Grosso do Sul (UFMS), Campo Grande, MS, Brazil.

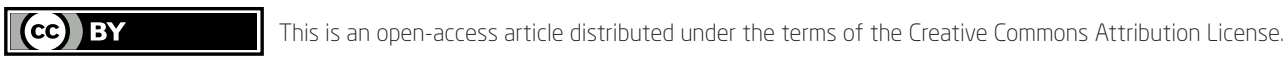

\footnotetext{
This paper may be copied, distributed, displayed, transmitted or adapted if provided, in a clear and explicit way, the name of the journal, the edition, the year and the pages on which the paper was originally published, but not suggesting that RAM endorses paper reuse. This licensing term should be made explicit in cases of reuse or distribution to third parties. It is not allowed the use for commercial purposes.

Este artigo pode ser copiado, distribuído, exibido, transmitido ou adaptado desde que citados, de forma clara e explícita, o nome da revista, a edição, o ano e as páginas nas quais o artigo foi publicado originalmente, mas sem sugerir que a RAM endosse a reutilização do artigo. Esse termo de licenciamento deve ser explicitado para os casos de reutilização ou distribuição para terceiros. Não é permitido o uso para fins comerciais.
} 


\section{ABSTRACT}

Purpose: The purpose of this writing is to analyze the activities of the retail supermarket in order to propose value to its clients, describing and associating them in their respective sources of value identified by a Value Creation Activities Model-Supermarket (VCAM-S). Additionally, we seek to identify the words that best represent the meaning of "proposing value" and the product categories of the supermarket that most clients value.

Originality/value: The development and implementation of VCAM-S works to identify new value activities in the supermarket. Based on this application, it is intended to suggest activities that enhance the delivery of value to the client.

Design/methodology/approach: Bibliographical research and field research were carried out. Twelve retail supermarket specialists were interviewed, including managers, entrepreneurs and consultants with at least eight years of experience in the supermarket sector. Through the qualitative approach, a script of semi-structured interviews with open questions was used. Later, the statements were transcribed and analyzed through the technique of content analysis.

Findings: The VCAM-S identified 8 value proposition activities, 71 subactivities and five value sources. It was found that the product categories "FFV", "Butcher" and "Bakery" were the sections that most proposed value to customers. The words that best represent the meaning of "proposing value" are service, convenience, location, variety and price. The results of the research contribute to the current debate on value and adapt the traditional VCAM to the retail supermarket. The VCAM-S allows for the identification and prospection of value propositions from the perspective of companies, associating them with valuable sources and activities.

\section{KEYWORDS}

VCAM-Supermarket. Value proposition. Iramuteq. Supermarket. Marketing. 


\section{INTRODUCTION}

In Brazil, food expenses account for approximately $19.80 \%$ of family budget expenditures (Instituto Brasileiro de Geografia e Estatística, 2010), and self-service retailing plays an important role in meeting this demand. Currently, the sector has 84.5 thousand stores, generates 1.85 million jobs and contributes $5.35 \%$ to the Gross Domestic Product (Associação Brasileira de Supermercados [Abras], 2016).

Even in view of the representativeness of self-service retail, there was a significant drop in the gross margin (4.4\% from 2015 to 2016) and in the market share (from $62 \%$ in 2014 to $61 \%$ in 2015) of supermarkets, in comparison with growth expressed in other formats, such as wholesales, which had a growth of $14.1 \%$ in its sales and increased its market share by 2\% (Associação Brasileira de Supermercados [Abras], 2017).

Given this scenario, supermarkets need to look for ways to remain competitive. In this sense, strategies related to the provision of value to the client can help this purpose. Considering the economic and social importance of supermarkets, they were chosen as the object of study for this research.

There are several definitions of value (Salem Khalifa, 2004; Lindgreen \& Wynstra, 2005; Lindgreen, Hingley, Grant, \& Morgan, 2012), but there is still no consensus in the literature. In general, the concept of value is based on the consumer's perception of the sacrifices (costs) and the benefits of an offer. Value creation can be defined by subjective perceptions and evaluations of the total experience of the customer when consuming a good or service. The competitive advantage refers to the use of resources and the ability of the company to create potential value for the client (Anderson, Narus, \& Van Rossum, 2006).

The company's ability to offer value to the customer is characterized as a competitive advantage, through the use of its resources. However, it is important that this value proposition is also evaluated from the customer perspective (Anderson et al., 2006). In this sense, the value proposition is "an encapsulation of a strategic management decision on what the company believes its customers value the most and what it is able to deliver in a way that gives it competitive advantage" (Rintamäki, Kuusela, \& Mitronen, 2007, p. 624).

Considering the importance of the concept of value, both in theoretical and strategic terms, this study aims to verify the value proposition used by the supermarkets in the city of Campo Grande (MS), Brazil. For this purpose, it was used the Value Creation Activities Model (VCAM) suggested by 
Lindman, Pennanen, Rothenstein, Scozzi, and Vincze (2016). It is a model that supports the sources, types and value activities developed in the fields of marketing, operations management, strategies and organization (Lindman et al., 2016). The VCAM allows companies to evaluate their activities according to the value proposition, considering their positioning, possible weaknesses, contradictions and/or opportunities for improvement.

The application of VCAM in supermarkets becomes one of the innovations of this study since it provides specific vision of the activities performed by the analyzed companies with the aim to propose value to the client. In addition, it can serve as a guide for other companies in the industry, in the value proposition. It should be noted that, in the reviewed literature, no references were found that address (in detail) the value proposition in the supermarket sector. This is the gap to be filled by this research.

This study is divided into five sections. This introduction is the first one. The second section approaches the theoretical framework of the research, while the third one dedicates itself to presenting the methodology. The fourth section highlights and discusses the results of the research and the fifth deals with the final considerations.

\section{THEORETICAL FRAMEWORK}

\subsection{Value proposition}

To understand the concepts related to value proposition, it is important to make a brief contextualization about the evolution of traditional marketing logic. Initially, Good Dominant Logic (GDL) dominated, focusing only on products. The focus was on the transaction and transfer of ownership for sale, with economic exchange being the essence of the GDL.

The value was incorporated during the manufacturing, and the role of the companies was based on the production and distribution of value. The emergence of a new logic presented by Service Dominant Logic (SDL) emphasized that companies do not create value for the customer, they only offer value propositions, and value is created by the customer (Vargo \& Lusch, 2008).

Business activities facilitate the integration of resources by developing value propositions to support customers in their value-creating consumer activities. In this sense, the value proposition is equivalent to a position statement since it defines the target customer, why the customer should buy and what the company is selling, and it is not limited to the purpose of communication (Webster Jr., 1994). 
In the literature, there are some theoretical models that aim to classify activities of the firms. Among them, we highlight the Porter value chain, which classifies an organization's value-adding activities in primary activities (which include entry logistics, operations, exit logistics, marketing, sales and services) and support activities (including infrastructure, human resources management, technology, and procurement). However, such a classification is not very comprehensive, failing to present details of how value aggregation can be made. In a different perspective from Porter, there is the Value Creation Activities Model (VCAM), which was used in this research. In VCAM, the level of activity decomposition is greater, increasing managerial knowledge about the process of value proposition by connecting to this structure, to the sources, types and value activities developed by the companies.

\subsection{Value Creation Activities Model (VCAM)}

Lindman et. al. (2016) developed the VCAM based on a framework embedded in a revised version of the value proposition structure developed by Smith and Colgate (2007), which organized sources and value types. The VCAM is composed by 9 main activities that break down into 108 sub-activities (Figure 2.2.1).

The VCAM differs from existing models because it allows the development of managerial knowledge through the process of value creation, interconnecting value proposition activities with possible sources and types of value (Lindman et al., 2016). This was the reason why the VCAM was chosen to subsidize this research.

(Figure 2.2.1)

ACTIVITIES FOR VALUE PROPOSITION

\begin{tabular}{cll}
\hline N. & \multicolumn{1}{c}{ Activity } & \multicolumn{1}{c}{ Focus } \\
\hline 1 & $\begin{array}{l}\text { Providing product- } \\
\text {-related attributes }\end{array}$ & $\begin{array}{l}\text { It involves sub-activities aimed at providing attributes related } \\
\text { to materials, design, environment, quality, technology, } \\
\text { modification opportunities, packaging, customization } \\
\text { opportunities, and/or craft products. }\end{array}$ \\
& & It involves price-related sub-activities, i.e., the provision of \\
& & $\begin{array}{l}\text { good value for money, the provision of price-related features } \\
\text { (e.g., high-priced or low-priced products) and the provision of } \\
\text { discounts. }\end{array}$ \\
& &
\end{tabular}




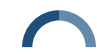

Paulo R. Condi, Dario de O. Lima-Filho, Caroline P. S. Finocchio, Filipe Quevedo-Silva

\section{(Figure 2.2.1 (conclusion))}

ACTIVITIES FOR VALUE PROPOSITION

\begin{tabular}{|c|c|c|}
\hline N. & Activity & Focus \\
\hline 3 & $\begin{array}{l}\text { Providing wider range } \\
\text { of product offering }\end{array}$ & $\begin{array}{l}\text { It involves sub-activities aiming at the assortment, the offer of } \\
\text { vertical or combined products, different offers of products and } \\
\text { complementary products related to the product. }\end{array}$ \\
\hline 4 & $\begin{array}{l}\text { Improving/ } \\
\text { Innovating products }\end{array}$ & $\begin{array}{l}\text { It involves sub-activities aimed at providing product innovation } \\
\text { (incremental and/or radical innovation) and providing new } \\
\text { products / services frequently. }\end{array}$ \\
\hline 5 & $\begin{array}{l}\text { Providing additional } \\
\text { services }\end{array}$ & $\begin{array}{l}\text { It involves sub-activities aimed at providing services such as } \\
\text { information about the company and/or products, services } \\
\text { related to the purchase (e.g., best price guarantee), delivery } \\
\text { service and installation services (for example), use/ } \\
\text { maintenance. }\end{array}$ \\
\hline 6 & Providing sales support & $\begin{array}{l}\text { It involves sub-activities aimed at the provision of facility } \\
\text { management support (e.g., management of a display section), } \\
\text { means of sales (e.g., direct assistance to resellers during sales), } \\
\text { sales assistance by company employees and/or courses to } \\
\text { educate retailers to sell the products. }\end{array}$ \\
\hline 7 & $\begin{array}{l}\text { Providing distribution } \\
\text { channels }\end{array}$ & $\begin{array}{l}\text { Involves sub-activities aimed to the provision of different } \\
\text { distribution channels (i.e., direct channel(s), indirect channel(s), } \\
\text { both direct and indirect channels, and/or appropriate channels } \\
\text { in the view of the customer) }\end{array}$ \\
\hline 8 & Promoting the product & $\begin{array}{l}\text { Involves sub-activities performed to advertise a specific } \\
\text { product. }\end{array}$ \\
\hline 9 & $\begin{array}{l}\text { Communicating the } \\
\text { brand }\end{array}$ & $\begin{array}{l}\text { Involves sub-activities performed to advertise a specific } \\
\text { product. }\end{array}$ \\
\hline
\end{tabular}

Source: Adapted from Lindman et al. (2016).

Value activities are concrete actions that companies undertake to propose potential value (Rintamäki et al., 2007; Grönroos \& Voima, 2013). Business activities related to proposing value can be classified as those that facilitate the value proposition of clients by providing potential resources (such as goods) and those that can facilitate the co-creation of value (e.g., store support with interaction between the firm and the customer).

VCAM was developed through a multiple case study conducted by Lindman et al. (2016) in 65 furniture industry companies from Finland, Germany, Italy, Spain, and Sweden. It was structured using the logic of 
Malone, Crowston, and Herman (2003), which aims to establish the basis for a systematic and powerful method of organizing and sharing business logic, concentrating on the concepts of activity and processes.

The authors suggest that future research should use the VCAM framework to evaluate other industries/manufacturing and service sectors, but they recommendthe framework to be modified so that it also corresponds to the context of each sector (Lindman et al., 2016). At the suggestion of the authors, this research applies the VCAM in retail self-service, specifically, in the retail supermarket. This sector was chosen due to its economic and social relevance, as well as the potential contribution of this study to the sector.

\subsection{Types and sources of value}

After completing a complex review in the literature, Smith and Colgate (2007) categorized four types of value (cost/sacrifice, functional/ instrumental, experiential/hedonic and symbolic/expressive) and five sources of value: Information, Interaction, Products, Environment, and Ownership/Possession Transfer (Figure 2.3.1).

\section{(Figure 2.3.1)}

VALUE PROPOSITION FRAMEWORK

\begin{tabular}{|c|c|c|c|c|}
\hline \multirow[b]{2}{*}{$\begin{array}{l}\text { Sources } \\
\text { of Value }\end{array}$} & \multicolumn{4}{|c|}{ Types of Value } \\
\hline & $\begin{array}{c}\text { Functional/ } \\
\text { Instrumental Value }\end{array}$ & $\begin{array}{l}\text { Experiential/ } \\
\text { Hedonic Value }\end{array}$ & $\begin{array}{l}\text { Symbolic/ } \\
\text { Expressive Value }\end{array}$ & $\begin{array}{l}\text { Cost/Sacrifice } \\
\text { Value }\end{array}$ \\
\hline & $\begin{array}{l}\text { - Correct/accurate } \\
\text { attributes } \\
\text { - Appropriate } \\
\text { performances } \\
\text { - Appropriate } \\
\text { outcomes }\end{array}$ & $\begin{array}{l}\text { - Sensory } \\
\text { - Emotional } \\
\text { - Social/relational } \\
\text { - Epistemic }\end{array}$ & $\begin{array}{l}\text { - Self-identity/ } \\
\text { worth } \\
\text { - Personal meaning } \\
\text { - Self-expression } \\
\text { - Social meaning } \\
\text { - Conditional } \\
\text { meaning }\end{array}$ & $\begin{array}{l}\text { - Economic } \\
\text { - Psychological } \\
\text { - Personal } \\
\text { investment } \\
\text { - Risk }\end{array}$ \\
\hline Information & $\begin{array}{l}\text { The information } \\
\text { informs, educates, } \\
\text { and helps } \\
\text { customers realize } \\
\text { performance and } \\
\text { outcomes. }\end{array}$ & $\begin{array}{l}\text { Copy and creativity } \\
\text { can provide or } \\
\text { enhance sensory, } \\
\text { emotional, } \\
\text { relational, and } \\
\text { epistemic } \\
\text { experiences. }\end{array}$ & $\begin{array}{l}\text { Can position a } \\
\text { product, help } \\
\text { consumers identify } \\
\text { with the product, } \\
\text { help them make } \\
\text { associations, and } \\
\text { interpret meaning. }\end{array}$ & $\begin{array}{l}\text { Helps consumers } \\
\text { evaluate } \\
\text { alternatives; make } \\
\text { more informed, } \\
\text { faster, and less } \\
\text { stressful decisions; } \\
\text { helps lower prices } \\
\text { by greater } \\
\text { competition. }\end{array}$ \\
\hline
\end{tabular}

(continue) 


\section{(Figure 2.3.1 (continuation)) \\ VALUE PROPOSITION FRAMEWORK}

\begin{tabular}{|c|c|c|c|c|}
\hline \multirow[b]{2}{*}{$\begin{array}{l}\text { Sources } \\
\text { of Value }\end{array}$} & \multicolumn{4}{|c|}{ Types of Value } \\
\hline & $\begin{array}{c}\text { Functional/ } \\
\text { Instrumental Value }\end{array}$ & $\begin{array}{l}\text { Experiential/ } \\
\text { Hedonic Value }\end{array}$ & $\begin{array}{l}\text { Symbolic/ } \\
\text { Expressive Value }\end{array}$ & $\begin{array}{c}\text { Cost/Sacrifice } \\
\text { Value }\end{array}$ \\
\hline Products & $\begin{array}{l}\text { Products directly } \\
\text { provide features, } \\
\text { functions, and } \\
\text { characteristics that } \\
\text { allow performances } \\
\text { and outcomes. }\end{array}$ & $\begin{array}{l}\text { They provide } \\
\text { sensory, emotional, } \\
\text { relational and } \\
\text { epistemic } \\
\text { experiences: } \\
\text { augmenting goods } \\
\text { or as the focal } \\
\text { product. }\end{array}$ & $\begin{array}{l}\text { Products enhance } \\
\text { consumer self- } \\
\text { concepts, provide } \\
\text { personal meaning, } \\
\text { offer self- } \\
\text { expression and } \\
\text { provide social } \\
\text { meaning. }\end{array}$ & $\begin{array}{l}\text { Product price and } \\
\text { augmented product } \\
\text { considerations, such } \\
\text { as operating costs, } \\
\text { assembly, ease of } \\
\text { use, warranty, and } \\
\text { service terms, help } \\
\text { to reduce costs and } \\
\text { sacrifices. }\end{array}$ \\
\hline Interactions & $\begin{array}{l}\text { Sales call frequency } \\
\text { and duration, } \\
\text { service interactions } \\
\text { and responsiveness, } \\
\text { and interactions } \\
\text { with systems (such } \\
\text { as the telephone, } \\
\text { billing, or customer } \\
\text { support system) } \\
\text { provide or enhance } \\
\text { desired } \\
\text { performances and } \\
\text { outcomes. }\end{array}$ & $\begin{array}{l}\text { Service attributes, } \\
\text { such as staff } \\
\text { politeness, } \\
\text { friendliness, or } \\
\text { empathy, create } \\
\text { sensory, emotional, } \\
\text { relational, and } \\
\text { epistemic } \\
\text { experiences for } \\
\text { customers, as do } \\
\text { servisse recovery, } \\
\text { customer support, } \\
\text { and other systems. }\end{array}$ & $\begin{array}{l}\text { Staff and system } \\
\text { interactions can } \\
\text { make customers } \\
\text { feel better about } \\
\text { themselves and } \\
\text { provide personal } \\
\text { meaning to } \\
\text { customers; } \\
\text { privileged } \\
\text { interactions support } \\
\text { status and prestige. } \\
\text { Equity policies can } \\
\text { enhance } \\
\text { sociocultural } \\
\text { meaning. }\end{array}$ & $\begin{array}{l}\text { Interactions with } \\
\text { people and systems } \\
\text { (such as electronic } \\
\text { data interchange) } \\
\text { add to or reduce the } \\
\text { economic and } \\
\text { psychological cost } \\
\text { of a product and } \\
\text { increase or reduce } \\
\text { the personal } \\
\text { investment required } \\
\text { to acquire and } \\
\text { consume the } \\
\text { product. }\end{array}$ \\
\hline Environment & $\begin{array}{l}\text { Furniture, fixtures, } \\
\text { lighting, layout, and } \\
\text { other decorative } \\
\text { features and } \\
\text { attributes of the } \\
\text { purchasing or } \\
\text { consumption } \\
\text { environment } \\
\text { contribute to } \\
\text { functional/ } \\
\text { instrumental value } \\
\text { by enhancing or } \\
\text { detracting from } \\
\text { product } \\
\text { performances and } \\
\text { outcomes. }\end{array}$ & $\begin{array}{l}\text { Features and } \\
\text { attributes of the } \\
\text { purchasing or } \\
\text { consumption } \\
\text { environment such } \\
\text { as music, ambiance, } \\
\text { and atmosphere can } \\
\text { create sensory, } \\
\text { emotional, and } \\
\text { epistemic } \\
\text { experiences for } \\
\text { customers. }\end{array}$ & $\begin{array}{l}\text { Where a product is } \\
\text { purchased or } \\
\text { consumed can } \\
\text { provide personal, } \\
\text { social, or } \\
\text { sociocultural } \\
\text { meaning and can } \\
\text { enhance self-worth } \\
\text { and expression-a } \\
\text { cup of coffee at an } \\
\text { outdoor cafe may } \\
\text { have more symbolic } \\
\text { value than coffee at } \\
\text { home. }\end{array}$ & $\begin{array}{l}\text { Contributes to the } \\
\text { economic cost of a } \\
\text { product (e.g." } \\
\text { popcorn at a movie } \\
\text { theater), } \\
\text { psychological cost } \\
\text { (such as finding } \\
\text { parking downtown), } \\
\text { personal investment } \\
\text { (how much } \\
\text { searching is } \\
\text { required), and risk } \\
\text { (personal safety). }\end{array}$ \\
\hline
\end{tabular}




\begin{tabular}{|c|c|c|c|c|}
\hline \multirow[b]{2}{*}{$\begin{array}{l}\text { Sources } \\
\text { of Value }\end{array}$} & \multicolumn{4}{|c|}{ Types of Value } \\
\hline & $\begin{array}{c}\text { Functional/ } \\
\text { Instrumental Value }\end{array}$ & $\begin{array}{l}\text { Experiential/ } \\
\text { Hedonic Value }\end{array}$ & $\begin{array}{l}\text { Symbolic/ } \\
\text { Expressive Value }\end{array}$ & $\begin{array}{c}\text { Cost/Sacrifice } \\
\text { Value }\end{array}$ \\
\hline $\begin{array}{c}\text { Ownership/ } \\
\text { Possession } \\
\text { Transfer }\end{array}$ & $\begin{array}{l}\text { Correct, accurate, } \\
\text { and timely } \\
\text { fulfillment } \\
\text { processes (such as } \\
\text { order taking, } \\
\text { picking/packing, and } \\
\text { delivery) provide } \\
\text { functional/ } \\
\text { instrumental value. }\end{array}$ & $\begin{array}{l}\text { Fulfilling delivery } \\
\text { promises and how a } \\
\text { product is delivered } \\
\text { (such as the } \\
\text { presentation of a } \\
\text { meal) can enhance } \\
\text { the customer } \\
\text { experience-as can } \\
\text { pride of ownership } \\
\text { and product } \\
\text { potency (future } \\
\text { potential). }\end{array}$ & $\begin{array}{l}\text { How a product is } \\
\text { delivered (such as } \\
\text { gift wrapped or via } \\
\text { a ceremony) and by } \\
\text { whom (such as the } \\
\text { manager of a car } \\
\text { dealership) can } \\
\text { create symbolic } \\
\text { value. }\end{array}$ & $\begin{array}{l}\text { Can be enhanced } \\
\text { with payment } \\
\text { terms, delivery } \\
\text { options, return } \\
\text { policies, billing } \\
\text { accuracy, order } \\
\text { tracking systems, } \\
\text { access to supplier } \\
\text { personnel, and } \\
\text { dispute resolution } \\
\text { procedures. }\end{array}$ \\
\hline
\end{tabular}

Source: Adapted from Smith \& Colgate (2007).

\section{METHODOLOGY}

The research was conducted under the perspective of the qualitative approach, which was carried out in two stages. The first stage was composed of a bibliographic review in which articles were researched and analyzed in the areas of marketing and retail supermarkets. From this stage, the concepts of value proposition, types, sources and value proposition activities based on the VCAM emerged (Lindman et al., 2016). The bibliographical research provided the theoretical basis necessary for the construction of the semi-structured script with guiding questions about value proposition, loyalty, innovation, expectation, strategies and tendencies to identify value activities and their respective sources of value (Appendix A).

The second stage consisted of the collection of primary data with 12 professionals from the supermarket sector. These professionals hold positions such as manager, entrepreneur and/or self-employed consultant of the supermarket, and have self-declared experience in this sector for at least eight years. Personal interviews were conducted between December (2017) and January (2018). Two interviews were conducted by video conference since the respondents lived in other states.

After transcription, each interview was read and re-read several times to enable in-depth analysis. At this stage, the essence of the discourse was 
observed and then the nucleus of each testimony was extracted. With this, it was possible to identify the frequency of value proposition activities, sources and types of value developed by supermarkets to propose value to the customer. We also used the software IRAMUTEQ (Version 3.1.2) to perform the textual descriptive statistics and access the word cloud.

Value proposition activities were grouped according to the VCAM. However, there was a need to make some adjustments to the value activities initially proposed. The authors, Lindman et al. (2016), suggested modifying and/or adapting the model to the sector surveyed. The adaptations are presented in Figure 3.1 and, by virtue of them, the model was renamed Value Creation Activities Model-Supermarket (VCAM-S).

\section{(Figure 3.1)}

ADAPTATIONS OF VCAM TO VCAM-S

\begin{tabular}{|c|c|c|c|}
\hline \multicolumn{2}{|r|}{ VCAM } & \multicolumn{2}{|r|}{ VCAM-S } \\
\hline N. & Activity & N. & Activity \\
\hline 1 & Providing product-related attributes & 1 & Store attribute \\
\hline 2 & Pricing & 2 & Pricing \\
\hline 3 & Providing wider range of product offering & 3 & Wide range of products \\
\hline 4 & Improving/ innovating products & 4 & Innovation in products \\
\hline 5 & Providing additional services & 5 & Additional services \\
\hline 6 & Providing sales support & 6 & Strategies/Processes \\
\hline 7 & Providing distribution channels & 7 & Channels of distribution \\
\hline 8 & Promoting the product & \multirow{2}{*}{8} & \multirow{2}{*}{ Communication } \\
\hline 9 & Communicating the brand & & \\
\hline
\end{tabular}

Source: Elaborated by the authors.

In order to establish the identification of activities in a more intuitive and objective way, it was decided that the names of the activities (based on the words that denote the essence of the activity) would be reduced. For example, instead of maintaining the nomenclature of Activity 3, "Providing wider range of product offering", we chose to call it "Wide range of products". The most significant modifications in the VCAM was made as follows:

The first was Activity 1, "Providing product-related attributes". This activity, in the original model, only deals with the tangible aspects and 
characteristics of products, such as materials, design and packaging. However, it should be noted that the supermarket itself is a product, that is, the supermarket product is composed by intangible factors such as service, additional services and consumption experience, amongst others. In this way, for better adherence of the VCAM to the retail supermarket, this activity came to be called "Store Attributes".

The second change refers to the withdrawal of Activity 6, "Providing sales support". Considering it is intrinsically linked to the support of tangible factors for products, such as installation and technical assistance, which are aspects that are inconsistent with the characteristics of the sector supermarket, the third change refers to the inclusion of an activity related to the strategies of the company, called "strategies/processes". This nomenclature was chosen after deep analysis of the interviews when there was an emergence of some value proposition activities that were directly linked to the management of the strategies and the processes of action of the companies.

The fourth amendment refers to the union of two activities (initially worked separately): "promote product" and "communicate brand". These activities have come to be called "communication" since they are related to the act of promoting, communicating and making known the product and company. In general terms, the value proposition activities of VCAM-S (Figure 3.2) are defined clearly:

Activity 1: "Store attributes" involves attributes related to the service (e.g., extended, good, cordial, differentiated, better, personalized, quality, and fast) and other store, features such as location, convenience, packaging, design, trust, and other atributes of the products such as quality, origin, traceability, quality seal, sustainability, organic, craft, and ethnic.

Activity 2: "Pricing" involves price sub-activities, i.e., the provision of good value for the money, the provision of price-related characteristics (affordable, low, correct, fair, and competitive), price research in relation to competitors, provision of discounts, progressive discounts and payment facilities (e.g., private label cards).

Activity 3: "Wide range of products" involves sub-activities aimed at assortment, variety, supply of vertical or combined products, offerings of complementary products. There is a mix of products with attributes of well-being (e.g., organic, sustainable, ecological, and healthy); cultural attributes (e.g., ethnic, regional, local, craft, typical, imported, and own); and practical attributes (e.g., ready, semi-ready, frozen, convenience, in individual packages, portions, and easy preparation). 
Activity 4: "Innovation in products" involves sub-activities aimed at providing incremental innovation of products and supplying new products with relative frequency, novelties, product launches with attributes of well-being, cultural, practicality and also radical innovations. It should be noted that an important innovation in supermarkets can also occur through the layout that is implemented, however in VCAM-S, it was decided to concentrate on the aspects that involve layout in Activity 1 ("Store attributes") since this activity encompasses correlated aspects such as circulation, convenience and product exposure.

Activity 5: "Additional services" involves sub-activities, aimed at the provision of services, such as information about the company and/or products, services related to purchasing (e.g., loyalty card, discount clubs or discount card), delivery services (e.g., home delivery, free delivery and delivery), the provision of integrated/shared spaces with other commercial activities focused on offering additional services to the customer (e.g., pharmacies, clothing stores, gifts, ATMs) and providing interaction with specialized staff (e.g., culinary experiences or cooking classes with chefs).

Activity 6: "Strategies/processes" deals with sub-activities related to store positioning, segmentation, market niche, target audience, consumption class, communication and marketing strategy, identifying and perceiving customer needs and knowing the customer to carry out the strategic management of value proposition for the client.

Activity 7: "Channels of distribution" involves sub-activities aimed at providing different distribution channels (direct and/or indirect), integration of the physical store and the virtual store and the combination of channels of distribution/interaction (omni channel).

Activity 8: "Communication" addresses sub-activities carried out to advertise a specific product/brand through personalized advertising, merchandising, marketing campaigns, sales strategies; communicates offers through traditional advertisements (e.g., radio, tabloids, leaflets, billboards, $\mathrm{TV}$ ); provides interaction through social media, WhatsApp, omni channel; supports activities and engagement in social responsibility actions (to promote the brand); and communicates the brand through direct marketing (focused on generating brand recall and providing promotional environment and weekly/monthly deals). 


\section{(Figure 3.2)}

\section{VALUE CREATION ACTIVITIES MODEL-SUPERMARKET (VCAM-S)}

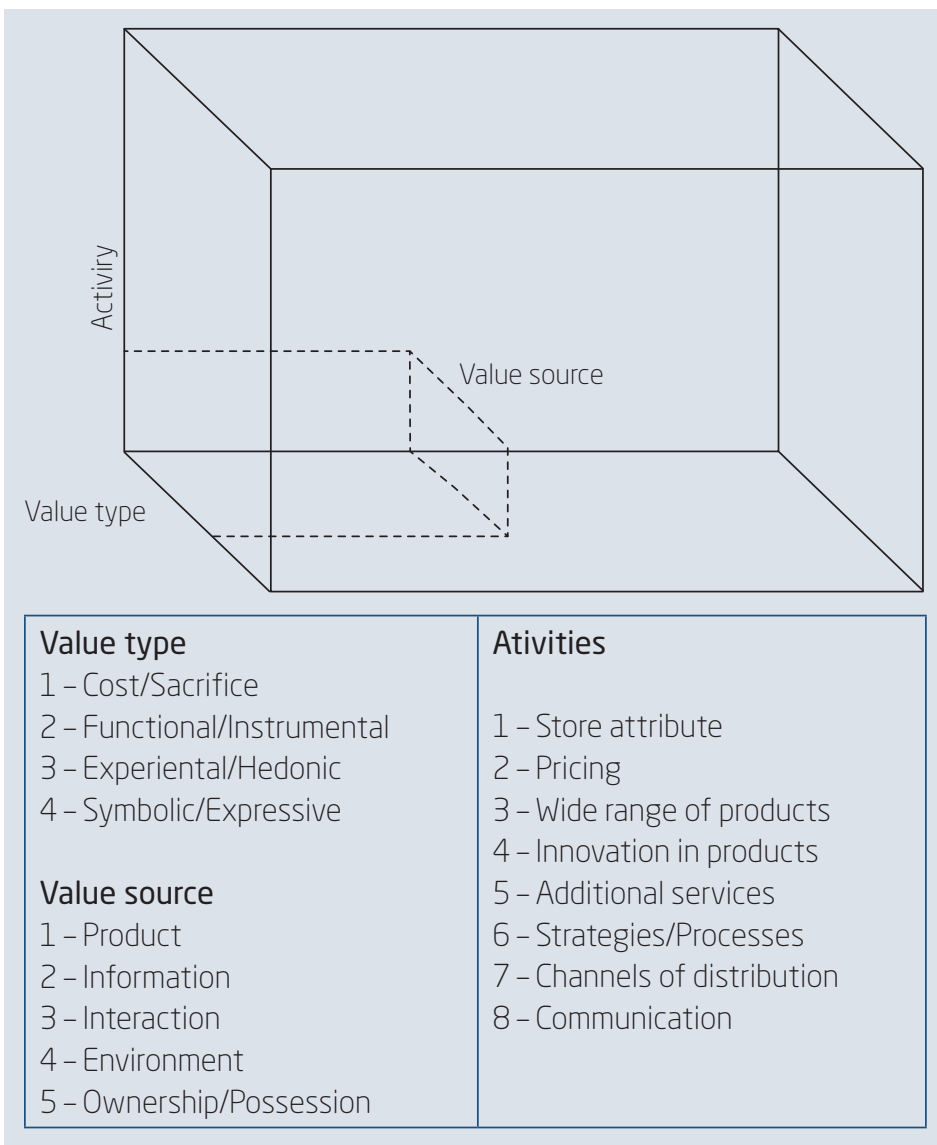

Source: Elaborated by the authors.

\section{RESULTS AND DISCUSSION}

Twelve participants were interviewed, of which $58 \%$ are male and $42 \%$ are female. The average age of the interviewees is 41 years old, the youngest is 28 and the oldest 58. An average, they have 14 years of work experience in the supermarket sector, and $83 \%$ of the participants are postgraduate.

The 12 interviews resulted in a total of approximately 353 minutes of audios with an average of 29 minutes per interview. With the statistical analysis of the Iramuteq software, it was verified that the general corpus consisted of 12 texts (statements), separated into 1,529 text segments (ST), 


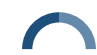

with text segments having an average of 3 lines. Thirty-five thousand one hundread and sixty-two occurrences (words, forms of words) emerged, including 3,577 distinct words and 1,760 words with a single occurrence.

Through the word cloud (Figure 4.1) it was possible to visualize the words obtained through the participants' statements. The words that emerged most frequently were: shop, customer, people, supermarket, product, quality, consumer purchase, price, and service. It was possible to verify that the word "store" presented 353 occurrences and was associated with the activities of "Store attributes" as well as associated to different store formats and marketing channels. The word "customer" presented 307 occurrences, being associated with the company/customer relationship. The word "supermarket" presented 286 occurrences. This high number of occurrences attributed to the fact that it is the object of study. The other words generally expressed what the supermarket proposed and what the customer expected to find (i.e., product, quality, price, and service).

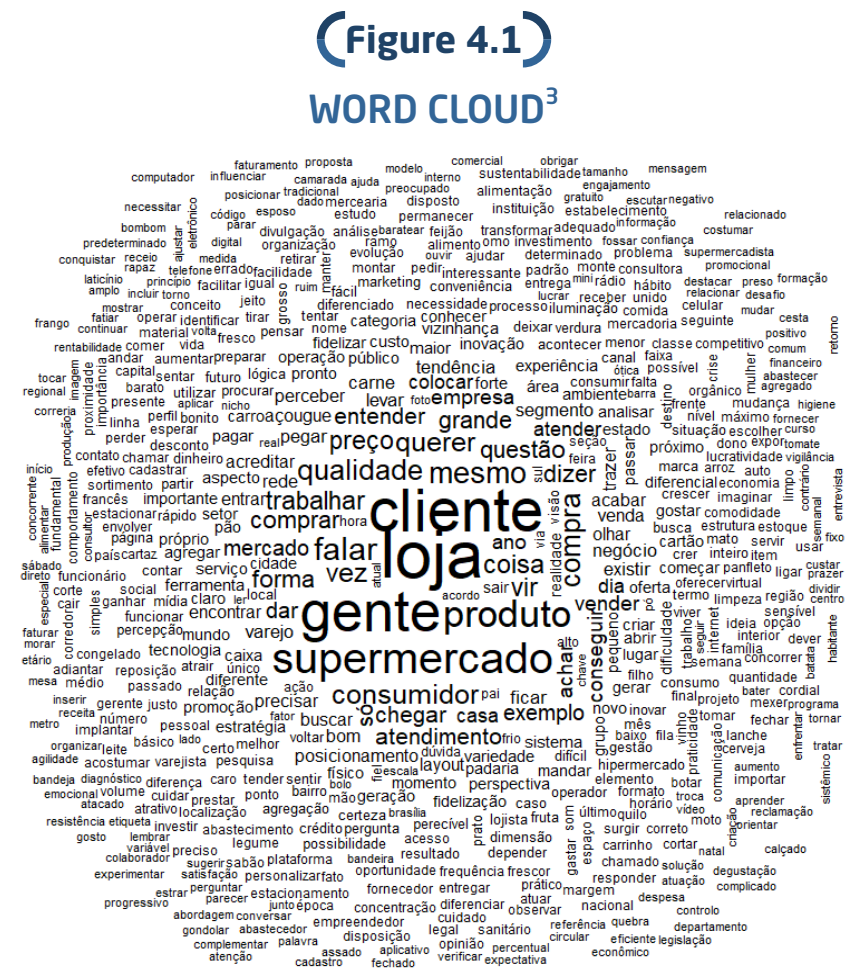

Source: Elaborated by the authors.

The word cloud was maintained in the original language, as they are the result of interviews conducted in Portuguese. 
In the systematization of data, we chose to present the frequency of each activity, sub-activity and source of value according to the information obtained from the interviews (Figure 4.2).

\section{(Figure 4.2)}

\section{NUMBER OF OCCURRENCES OF VCAM-S ACTIVITIES}

\begin{tabular}{lccc}
\multicolumn{1}{c}{$\begin{array}{c}\text { Value proposition } \\
\text { activity }\end{array}$} & $\begin{array}{c}\text { Number of } \\
\text { subactivities }\end{array}$ & $\begin{array}{c}\text { Number of } \\
\text { occurrences }\end{array}$ & \% of occurrences \\
\hline Store attributes & 24 & 167 & $47 \%$ \\
\hline Strategies/processes & 14 & 52 & $15 \%$ \\
\hline Wide range of products & 6 & 41 & $11 \%$ \\
\hline Pricing & 5 & 32 & $9 \%$ \\
\hline Communication & 9 & 26 & $7 \%$ \\
\hline Innovation in products & 5 & 16 & $4 \%$ \\
\hline Additional services & 5 & 16 & $4 \%$ \\
\hline Channels of distribution & 3 & 8 & $2 \%$ \\
\hline Total & 71 & 358 & $100 \%$ \\
\hline
\end{tabular}

Source: Elaborated by the authors.

Three hundred and fifty eight value proposition activities (Appendix B) were found. The "Store attributes/167" (47\%), "Strategies/processes/52" (15\%), and "Wide range of products /41" (11\%) were the most frequent. It should be noted that these three activities together represent $73 \%$ of the occurrences related to the value proposition activities identified in the VCAM-S.

In the "Store attributes/167" activity, we found 24 sub-activities that are related to "Product/50", "Environment/64" and "Interaction/53" value sources. Considering these values sources, we dismembered each one of them for a better understanding. Associating with the "Product/50" value source, there were 7 sub-activities. The "Provide quality and freshness/24" and "Provide attribute, credibility, traceability, quality seal, origin, sanitary control, hygiene, and health/11" emerged more frequently. The sub-activities, "Providing products related to product tasting/1" and "Providing products related to product design/1" showed less frequency.

We found nine sub-sources associated with the "Environment/64" value source. The results point to the sub-activities "Provide results related to the 
access, location, proximity, convenience, and practicality of the store/17", "Provide attributes related to store lighting, sonorization, odorization, and ventilation/10", and "The result is cleanliness, beauty and organization of the store/10" represented $73 \%$ of occurrences.

According to Martinelli and Balboni (2012), there is a causal relationship between perceived quality of service, customer satisfaction and loyalty. Quality of service plays an important role in activating the client's real behavior and it is promoted by the evaluation of three different dimensions: perceived quality of service, customer satisfaction and behavioral intentions. Consequently, quality of service is crucial in this context, being that retailers must meet and manage it carefully if they want to meet the needs of their customers and keep them loyal over time. The level of service quality allows supermarkets to be aware of the performance of the store's appearance and reliability attributes.

The activity "Strategies/processes/52" has 14 sub-activities. The sub-activities "Attributes linked to identifying, perceiving, meeting customer needs, knowing the customer, and generating value/8", "Attributes linked to store positioning, store strategy, segmentation, niche market, performance, target audience, and consumption class/7", "Attributes linked to sales strategy, customer attraction, offers, promotions, and promotional actions/7", and "Attributes linked to business management, costs, profitability, average ticket, customers potentials, price research, and lean management/7" were the most representative ( $54 \%$ of the total).

Considering the activities mentioned above, Churchill and Peter (2000) stated that positioning is directly related to creating a positive perception of the company vis-a-vis its competitors in the minds of potential buyers. In this way, establishing the positioning strategy, analyzing the target audience, the needs of the clients and the resources that the company has are ways of developing actions to propose value to the client.

The activity "Wide range of products /41" was the third most cited in the interviews, representing $11 \%$ of occurrences (Figure 4.2 ). It is composed by 6 sub-activities, including "Provide different product offerings aimed at the mix, assortment, variety, different offers and ideal mix/14", "Provide convenience in finding the products you need/are well-supplied/8", "Provide mix of products with well-being attributes (e.g., organic, sustainable, ecological, and healthy)/7", "Provide products launches and novelties/4", "Provide product mix with cultural attributes (e.g., ethnic, regional, local, artisan, typical, imported, own)/4", and "Provide product mix with attributes of practicality (e.g., ready, semi-ready, frozen , practical, portions, easy to prepare)/4". 
Considering the demand about food, especially organic, Chen (2007) points out the existence of a valuation of environmental awareness and safer foods as an attribute of choice in organic consumption. Silva and Paula (2007) identified that attributes such as practicality, convenience, speed, safety and quality are factors that influence the choice of consuming organic foods.

The fourth activity is "Pricing/32", representing 9\% of occurrences. Five sub-activities emerged: "Provide price (e.g., good pricing, correct and competitive)/20", "Provide good quality against price (e.g., fair price)/5", "Provide ease payment/4", "Provide low prices (e.g., affordable price)/1" and "Provide discounts (e.g., progressive discount)/1". This activity presented some singularities, evidencing that, from a company's perspective, proposing value for the customer in pricing is directly related to offering a product with the correct price, which is adherent and competitive in relation to the market, rather than simply offering a product centered on the lowest price.

Hassan (2012) has identified that customers pay for what creates value for them. Another aspect that should be considered is the relationship between quality and price. There is a category of customers that would be willing to pay a little more for higher quality products. It has also been identified that providing different forms of payment is a way of proposing value to the customer, since currently, with technological advances in digital media, applications and different payment systems together offer value through practicality, convenience, speed and time optimization.

The activity "Communication/26" represented $7 \%$ of the occurrences, being composed by nine sub-activities. Four sub-activities were associated with the "Interaction/Information" value source, four were associated with only the "Information" value source and one was associated with "Environment" source of value. This result informs the potential value proposed through "Provide a promotional environment with weekly, monthly offers $/ 6$ ". The "Communication" activity also showed that new media, such as social media and WhatsApp can be effective tools to both propagate actions related to the "Information" value source (for example, marketing campaigns and promotions) and to implement activities associated with source of value "Interaction" such as interacting with customers, narrowing relationships and generating engagement with the brand.

Direct customer interaction allows the company to communicate its brand/product quality directly to the customer. Along with emotional value, this direct interaction leads to the proposition of social/relational value.

The activities "Innovation in products/16" and "Additional services/16" presented the same number of occurrences, i.e, $4 \%$ each one. The "Additional 
services" activity consisted of five sub-activities, but the "Delivery of home, free delivery and delivery/5", "Providing integrated/shared spaces with other commercial activities focused on providing services (for example: pharmacy)/5", and "Provide loyalty programs (e.g., loyalty card, discount clubs or discount card)" were the most cited. Loyalty cards are a trend in current relationships with the consumer. The type of value proposed by this sub-activity is the experiential/hedonic value, since a trust relationship develops between the customer and the store.

The activity "Innovation in products/16" identified five sub-activities: "Providing new products with well-being attributes (e.g., organic, sustainable, ecological, and healthy)/6", "Provide new products with frequency/4", "Provide new products with cultural attributes (e.g., ethnic, regional, local, craft, typical, imported, own)/3", "Provide new products with practicality/easiness attributes (e.g., ready, semi-ready, frozen and ready-to-eat)/2", and "Improving existing products-incremental innovation (e.g., bread-making process)/1".

The results showed that the "Innovation in products/16" is intrinsically associated with the "Wide range of products" activity. This happened because some attributes of the products, such as products with cultural attributes, can be related to both activities.

The activity "Channels of distribution" showed the lowest number of occurrences (at 8 of a total of 358 ) representing only $2 \%$ of the total. This activity was composed of three sub-activities: "Provide different direct Channels of Distribution (e.g., a virtual store)/5", "Provide physical store and virtual store integration/2" and "Provide a combination of direct and indirect Channels of Distribution (omni channel)/1".

When questioned about which categories of products offer the most value to customers, there was an express participation in the sections "FFV", "Butcher" and "Bakery", which were declared by at least 8 of the 12 interviewees (Figure 4.3).

\section{(Figure 4.3)}

\section{SECTIONS THAT MOST PROPOSE VALUE TO THE CLIENT}

\begin{tabular}{|c|c|c|}
\hline Sections & Absolute Frequency & Relative Frequency \\
\hline FFV & 9 & $25 \%$ \\
\hline Butcher & 8 & $22 \%$ \\
\hline Bakery & 8 & $22 \%$ \\
\hline
\end{tabular}


(Figure 4.3 (conclusion))

SECTIONS THAT MOST PROPOSE VALUE TO THE CLIENT

\begin{tabular}{lcc}
\multicolumn{1}{c}{ Sections } & Absolute Frequency & Relative Frequency \\
\hline Rotisseria & 4 & $11 \%$ \\
\hline Cold Cuts & 2 & $6 \%$ \\
\hline Checkout & 2 & $6 \%$ \\
\hline Dairy Products & 1 & $3 \%$ \\
\hline Fishmonger & 1 & $3 \%$ \\
\hline Frozen Foods & 1 & $3 \%$ \\
\hline Total & 36 & $100 \%$ \\
\hline
\end{tabular}

Source: Elaborated by the authors.

The interviewees were also asked (at the end of the interviews) which words best represent the meaning of a value proposition in a supermarket. The results presented in Figure 4.4 show that proposing value means offering good service, quality, personalized assistance, fast results, and a focus on the convenience of the client.

The results also indicated that $74 \%$ of the words mentioned were related to the activities of "Store attributes", it was identified by the words: service, convenience, location, environment, parking, product, and consumption experience.

Similar results were found by Hassan (2012), in research on value proposition in supermarkets. The results showed that the majority of customers think that the highest value delivered is the location of the store, followed by product quality, price, loyalty card, product mix, and promotion. 


\section{(Figure 4.4)}

\section{MEANING OF VALUE PROPOSITION FOR THE CLIENT}

\begin{tabular}{|c|c|c|c|c|}
\hline $\begin{array}{l}\text { Meaning of } \\
\text { propose value }\end{array}$ & $\begin{array}{l}\text { Value } \\
\text { activity }\end{array}$ & $\begin{array}{l}\text { Number of } \\
\text { occurrences }\end{array}$ & $\begin{array}{c}\% \text { of } \\
\text { occurrences }\end{array}$ & $\begin{array}{l}\text { Activity / Number of } \\
\text { occurrences }\end{array}$ \\
\hline Service & $\begin{array}{l}\text { Store } \\
\text { attributes }\end{array}$ & 11 & \multirow{7}{*}{$74 \%$} & $\begin{array}{l}\text { Service/5; Fast/3; Custom/1; } \\
\text { Quality/1; with smile/1. }\end{array}$ \\
\hline Convenience & $\begin{array}{l}\text { Store } \\
\text { attributes }\end{array}$ & 5 & & $\begin{array}{l}\text { Convenience/2; Agility/2; } \\
\text { Practicality/1. }\end{array}$ \\
\hline Parking & $\begin{array}{l}\text { Store } \\
\text { attributes }\end{array}$ & 3 & & $\begin{array}{l}\text { Parking/1; Convenience/1; } \\
\text { Fast/1. }\end{array}$ \\
\hline Environment & $\begin{array}{l}\text { Store } \\
\text { attributes }\end{array}$ & 3 & & $\begin{array}{l}\text { Environment/1; Cleaning/1; } \\
\text { Organization/1. }\end{array}$ \\
\hline Location & $\begin{array}{l}\text { Store } \\
\text { attributes }\end{array}$ & 3 & & $\begin{array}{l}\text { Location/1; Easy access/1; } \\
\text { Facility/1. }\end{array}$ \\
\hline Product & $\begin{array}{l}\text { Store } \\
\text { attributes }\end{array}$ & 2 & & $\begin{array}{l}\text { with Freshness/1; with } \\
\text { quality/1; }\end{array}$ \\
\hline $\begin{array}{l}\text { Consumer } \\
\text { experience }\end{array}$ & $\begin{array}{l}\text { Store } \\
\text { attributes }\end{array}$ & 2 & & Consumer experience/2. \\
\hline $\begin{array}{l}\text { Value } \\
\text { generation }\end{array}$ & $\begin{array}{l}\text { Strategies/ } \\
\text { Processes }\end{array}$ & 1 & \multirow{3}{*}{$8 \%$} & Value generation/1. \\
\hline Profitability & $\begin{array}{l}\text { Strategies/ } \\
\text { Processes }\end{array}$ & 1 & & Profitability/1. \\
\hline Sustainability & $\begin{array}{l}\text { Strategies/ } \\
\text { Processes }\end{array}$ & 1 & & Sustainability/1. \\
\hline Variety & $\begin{array}{l}\text { Wide range of } \\
\text { products }\end{array}$ & 3 & $8 \%$ & $\begin{array}{l}\text { Wide range of products/1; } \\
\text { Variety/1; Meet/1. }\end{array}$ \\
\hline Price & Pricing & 3 & $8 \%$ & Price/1; Fair/I; Right/1. \\
\hline Novelty & $\begin{array}{l}\text { Innovation } \\
\text { in products }\end{array}$ & 1 & $3 \%$ & Novelty/1. \\
\hline Total & & 39 & $100 \%$ & \\
\hline
\end{tabular}

Source: Elaborated by the authors.

\section{FINAL CONSIDERATIONS}

The aim of this research was to analyze the value propositions of supermarket, considering the development and application of the VCAM-S 
in different supermarket companies. This fact constitutes the innovation of this paper and its contribution to the theoretical field.

The model incorporates (in a systematic way) the activities, sources and types of value, constituting a useful tool for the companies of the sector (since it can help in the planning of strategic actions oriented to the client). In addition, it allows companies to assess which activities are being performed and which are not, with a focus on value proposition. In this way, companies can evaluate how they behave in relation to defined value propositions. The evaluation of the positioning in relation to the activities supports companies in the discovery of weaknesses or contradictions.

The empirical results demonstrate that the activities "Store attributes", "Strategies/processes", "Wide range of products", "Pricing", "Communication", "Innovation in Products", "Additional Services", and "Channels of Distribution" (in this order) are the most relevant. In addition, it has been identified that the sections "FFV", "Butcher" and "Bakery" are the sections that most propose value to the client from the perspective of the interviewees.

The words that best represent the meaning of proposing value to the client, from the perspective of the interviewees, are: service, convenience, environment, parking, location, variety, and price, indicating their current strategies.

For future research, it is relevant to understand the application of VCAM-S from the perspective of the client to understand if the value proposed by the company is perceived effectively by the client. Another suggestion is the application of VCAM-S in different formats of food retail to identify activities and possible variations.

\section{PROPOSIÇÃO DE VALOR: APLICAÇÃO DO VALUE CREATION ACTIVITIES MODEL NO VAREJO SUPERMERCADISTA (VCAM-S)}

\section{) RESUMO}

Objetivo: Analisar as atividades do varejo supermercadista para propor valor ao seu cliente, descrevendo-as e associando-as em suas respectivas fontes de valor identificadas pelo Value Creation Activities Model-Supermarket (VCAM-S). Adicionalmente, busca-se identificar as palavras que melhor 
representam os significados de propor valor e as seções do supermercado que mais propõem valor aos clientes.

Originalidade/relevância: A aplicação do $V C A M-S$ inovou ao identificar novas atividades de valor. Com base nessa aplicação, pretende-se sugerir atividades que potencializem a entrega de valor ao cliente.

Principais aspectos metodológicos: Foi realizada uma pesquisa bibliográfica e posteriormente a pesquisa de campo, entrevistando 12 especialistas do varejo supermercadista, entre gerentes, empresários e consultores com experiência mínima de oito anos. Pela abordagem qualitativa, foi utilizado um roteiro de entrevistas semiestruturado com questões abertas; posteriormente, os depoimentos foram transcritos e analisados por meio da técnica de análise de conteúdo.

Síntese dos principais resultados: O VCAM-S identificou 8 atividades de proposição de valor, 71 subatividades e 5 fontes de valor. Constatou-se que as seções de "FLV", "Açougue" e "Padaria" são as seções que mais propõem valor para os clientes e as palavras que melhor representam o significado de propor valor são: atendimento, comodidade, ambiente, estacionamento, localização, variedade e preço. Os resultados da pesquisa contribuem para o debate atual sobre valor e adapta o VCAM tradicional para o varejo supermercadista. O VCAM-S permite a identificação e prospecção das proposições de valor na perspectiva das empresas, associando-as às fontes e atividades de valor.

\section{PALAVRAS-CHAVE}

VCAM-Supermarket. Proposição de valor. Iramuteq. Supermercado. Marketing.

\section{REFERENCES}

Associação Brasileira de Supermercados. (2016). Sales leaders: Brands that attract consumers. Retrieved from http://www.abras.com.br/edicoesanteriores/Main.php? MagID $=7 \&$ MagNo $=204$

Associação Brasileira de Supermercados. (2017). Ranking Abras 2016. Superhiper, 43 (188). Retrieved from http://www.abras.com.br/edicoes-anteriores/ Main.php? MagID $=7 \&$ MagNo=201 
Anderson, J. C., Narus, J. A., \& Van Rossum, W. (2006). Customer value propositions in business markets. Harvard Business Review, 84, 1-4.

Chen, M. F. (2007). Consumer attitudes and purchase intentions in relation to organic foods in Taiwan: Moderating effects of food-related personality traits. Food Quality and Preference, 18(7), 1008-1021. doi:10.1016/j. foodqual.2007.04.004

Churchill, G. A., \& Peter, P. J. (2000). Marketing: Creating value for customers. $\left(2^{\text {nd }}\right.$ ed.). São Paulo: Saraiva.

Grönroos, C., \& Voima, P. (2013). Critical service logic: Making sense of value creation and co-creation. Journal of the Academy of Marketing Science, 41 (2), 133-150. doi:10.1007/s11747-012-0308-3

Hassan, A. (2012). The value proposition concept in marketing: How customers perceive the value delivered by firms-A study of customer perspectives on supermarkets in Southampton in the United Kingdom. International Journal of Marketing Studies, 4(3), 68. doi:10.5539/ijms. v4n3p68

Instituto Brasileiro de Geografia e Estatísticas. (2009). Pesquisa de orçamento familiar 2008-2009: Despesas, rendimentos e condições de vida. Retrieved from http://biblioteca.ibge.gov.br/visualizacao/livros/liv45130.pdf

Lindgreen, A., \& Wynstra, F. (2005). Value in business markets: What do we know? Where are we going? Industrial Marketing Management, 34(7), 732-748. doi:10.1016/j.indmarman.2005.01.001

Lindgreen, A., Hingley, M. K., Grant, D. B., \& Morgan, R. E. (2012). Value in business and industrial marketing: Past, present, and future. Industrial Marketing Management, 41(1), 207-214. doi:10.1016/j.indmarman.2011. 11.025

Lindman, M., Pennanen, K., Rothenstein, J., Scozzi, B., \& Vincze, Z. (2016). The value space: How firms facilitate value creation. Business Process Management Journal, 22 (4), 736-762. doi:10.1108/BPMJ-09-2015-0126

Malone, T. W., Crowston, K., \& Herman, G. A. (2003). Organizing business knowledge: The MIT process handbook. Cambridge: MIT press.

Martinelli, E., \& Balboni, B. (2012). Retail service quality as a key activator of grocery store loyalty. The Service Industries Journal, 32(14), 2233-2247. doi:10.1080/02642069.2011.582499

Rintamäki, T., Kuusela, H., \& Mitronen, L. (2007). Identifying competitive customer value propositions in retailing. Managing Service Quality: An International Journal, 17(6), 621-634. doi:10.1108/09604520710834975 
Salem Khalifa, A. (2004). Customer value: a review of recent literature and an integrative configuration. Management Decision, 42 (5), 645-666. doi:10. 1108/00251740410538497

Silva, J. M. da, \& Paula, N. M. de. (2003). Changes in the pattern of food consumption in Brazil after de Real Plan. Paper presented at the meeting of Evento de Iniciação Científica da Universidade Federal do Paraná, Curitiba, PR.

Smith, J. B., \& Colgate, M. (2007). Customer value creation: A practical framework. Journal of Marketing Theory and Practice, 15(1), 7-23. doi:10.2753/ MTP1069-6679150101

Vargo, S. L., \& Lusch, R. F. (2008). From goods to service(s): Divergences and convergences of logics. Industrial marketing management, 37(3), 254-259. doi:10.1016/j.indmarman.2007.07.004

Webster Jr., F. E. (1994). Defining the new marketing concept (Part 1). Marketing management, 2(4), 22. 


\section{(APPENDiX A)}

(Figure A.1)

\section{SEMISTRUCTURED INTERVIEW SCRIPT}

\section{Questions}

How to propose value to supermarket customers?

How to keep customers in the supermarket?

Which sections most propose value to the customer?

How to innovate in supermarket?

What do customers expect to find in supermarkets?

What strategies do supermarkets use to attract customers?

What are the future trends for supermarkets?

Speak three words that best represent the meaning of a value proposition in a supermarket.

Source: Elaborated by the authors. 


\section{(APPENDIX B)}

\section{(Figure B.1)}

VCAM-S VALUE PROPOSITION ACTIVITIES

\begin{tabular}{lcc}
\hline 1. Value Proposition Activity "Store Attributes" & $\begin{array}{c}\text { Source of } \\
\text { value }\end{array}$ & $\begin{array}{c}\text { Number of } \\
\text { occurrences }\end{array}$ \\
\hline Provide attributes related to product/service quality &
\end{tabular}

Provide quality and freshness

Products

24

Provide product-related attributes

Provide attributes related to the convenience and convenience of the Products (e.g., portions, sliced, ready, and frozen dishes)

Products

6

Provide attributes related to trust, origin, credibility, traceability, quality seal, origin, sanitary control, and hygiene

Products

11

Provide attributes related to exposure, attractive, beautiful, and

harmonic presentation of products

Products $\quad 5$

Provide attributes related to product tasting

\begin{tabular}{lll} 
& Products & 1 \\
\hline P) & Products & 2
\end{tabular}

Provide attributes related to technology (e.g., electronic tags)

Provide standardized opportunities for modifications

Provide attributes related to product packaging design

Products

1

Provide service-related attributes

Provide attendance.

Interaction

15

Provide self-service (e.g., self-checkout machine).

Interaction

3

Provide attendance extended, extended service (e.g., 24 hours).

Interaction

1

Provide good service, quality, cordial, welcoming, value the customer, with respect, with smile and correct.

Interaction

13

Provide attributes related to experience of consumption and/or purchase.

Interaction

5

\begin{tabular}{lll}
\hline Provide attendance personalized, differentiated and quality service. & Interaction & 6 \\
\hline Provide service with agility and speed. & Interaction & 8 \\
\hline Provide care with trained, qualified and qualified staff. & Interaction & 2 \\
\hline
\end{tabular}

Provide store-related attributes

Provide attributes related to the store environment.

Environment

3 


\section{(Figure B.1 (continuation))}

VCAM-S VALUE PROPOSITION ACTIVITIES

\begin{tabular}{|c|c|}
\hline 1. Value Proposition Activity "Store Attributes" & $\begin{array}{l}\text { Source of } \\
\text { value }\end{array}$ \\
\hline
\end{tabular}

Provide attributes related to the store format (e.g., compact, minor, express Grab \& Go).

Environment 5

Provide attributes related to the store's internal layout, business environment, structure, and circulation.

Environment

7

Provide attributes related to the exposure of the sections/gondolas in an easy, bold and convenient way.

Environment

2

Provide attributes related to the lighting, sound, odor, sensoriality,

and ventilation of the store.

Environment $\quad 10$

Provide attributes related to the cleanliness, beauty and

organization of the store.

Environment

10

Provide attributes related to the ease of access, location, proximity,

convenience, convenience and convenience of the store.

Environment

Provide attributes related to parking, easy access, convenience, and availability of trolleys.

Environment

Provide attributes related to the facade, marquee and luminous of the store.

Environment

Total occurrences

167

2. Value Proposition Activity "Pricing"

Source of Number of

value occurrences

Provide good quality in relation to price (e.g., fair price).

Products

5

Provide low prices related features (e.g., affordable price).

Products

2

Provide price (e.g., good pricing, correct and competitive).

Products

20

Provide discounts (e.g., progressive discount).

Products

1

Provide ease of payment (e.g., own card, installment and private label).

Products

4

Total occurrences

32

3. Value Proposition Activity "Wide range of products"

Source of Number of

value occurrences

Provide different product offerings targeting the ideal mix, assortment, variety and different offerings.

Products

14

(continue) 


\section{(Figure B.1 (continuation))}

VCAM-S VALUE PROPOSITION ACTIVITIES

\begin{tabular}{|c|c|c|}
\hline 3. Value Proposition Activity "Wide range of products" & $\begin{array}{l}\text { Source of } \\
\text { value }\end{array}$ & $\begin{array}{l}\text { Number of } \\
\text { occurrences }\end{array}$ \\
\hline $\begin{array}{l}\text { Provide convenience in finding the products you need, in a } \\
\text { well-stocked store. }\end{array}$ & Products & 8 \\
\hline Provide products releases, novalty. & Products & 4 \\
\hline $\begin{array}{l}\text { Provide product mix with wellness attributes (e.g., organic, } \\
\text { sustainable, ecological, healthy) }\end{array}$ & Products & 7 \\
\hline $\begin{array}{l}\text { Provide mix of products with cultural attributes (e.g., ethnic, } \\
\text { regional, local, artisan, typical, imported, own) }\end{array}$ & Products & 4 \\
\hline $\begin{array}{l}\text { Provide product mix with attributes of practicality (e.g., ready, } \\
\text { semi-ready, frozen, practical, portions, easy preparation). }\end{array}$ & Products & 4 \\
\hline Total occurrences & & 41 \\
\hline 4. Value Proposition Activity "Innovation in Products" & $\begin{array}{l}\text { Source of } \\
\text { value }\end{array}$ & $\begin{array}{l}\text { Number of } \\
\text { occurrences }\end{array}$ \\
\hline $\begin{array}{l}\text { Improve existing products - incremental innovation (e.g., bread } \\
\text { making process). }\end{array}$ & Products & 1 \\
\hline Provide new products frequently. & Products & 4 \\
\hline $\begin{array}{l}\text { Provide new products with attributes of well-being (e.g., organic, } \\
\text { sustainable, ecological, healthy). }\end{array}$ & Products & 6 \\
\hline $\begin{array}{l}\text { Provide new products with cultural attributes (e.g., ethnic, regional, } \\
\text { local, artisan, typical, imported, own). }\end{array}$ & Products & 3 \\
\hline $\begin{array}{l}\text { Provide new products with practical attributes (e.g., ready, } \\
\text { semi-ready, frozen, practical, portions, easy preparation). }\end{array}$ & Products & 2 \\
\hline Total occurrences & & 16 \\
\hline 5. Value Proposition Activity "Additional Services" & $\begin{array}{l}\text { Source of } \\
\text { value }\end{array}$ & $\begin{array}{l}\text { Number of } \\
\text { occurrences }\end{array}$ \\
\hline \multicolumn{3}{|l|}{ Provision of consultancy/services related to information } \\
\hline $\begin{array}{l}\text { Provide interaction with specialized staff (e.g., culinary experience, } \\
\text { cooking class with chefs) }\end{array}$ & Information & 1 \\
\hline \multicolumn{3}{|l|}{ Provide purchase-related services } \\
\hline $\begin{array}{l}\text { Provide loyalty programs (e.g., loyalty card, discount clubs or } \\
\text { discount card) }\end{array}$ & Interaction & 4 \\
\hline
\end{tabular}




\section{(Figure B.1 (continuation))}

VCAM-S VALUE PROPOSITION ACTIVITIES

\begin{tabular}{|c|c|c|}
\hline 5. Value Proposition Activity "Additional Services" & $\begin{array}{l}\text { Source of } \\
\text { value }\end{array}$ & $\begin{array}{l}\text { Number of } \\
\text { occurrences }\end{array}$ \\
\hline \multicolumn{3}{|l|}{ Provision of delivery services } \\
\hline Delivery of home delivery, free delivery, delivery & $\begin{array}{l}\text { Ownership/ } \\
\text { Possession }\end{array}$ & 5 \\
\hline $\begin{array}{l}\text { Provide additional services focusing on the practicality and } \\
\text { attractiveness of customers (e.g., ATMs) }\end{array}$ & Products & 1 \\
\hline $\begin{array}{l}\text { Provide integrated / shared spaces with other business activities } \\
\text { focused on offering services (e.g., pharmacies) }\end{array}$ & Products & 5 \\
\hline Total occurrences & & 16 \\
\hline 6. Value proposition activity "Strategies / processes" & $\begin{array}{l}\text { Source of } \\
\text { value }\end{array}$ & $\begin{array}{l}\text { Number of } \\
\text { occurrences }\end{array}$ \\
\hline \multicolumn{3}{|l|}{ Supermarket strategic management } \\
\hline $\begin{array}{l}\text { Attributes linked to store positioning, store strategy, segmentation, } \\
\text { niche market, target audience, and consumption class. }\end{array}$ & $\begin{array}{l}\text { Ownership/ } \\
\text { Possession }\end{array}$ & 7 \\
\hline $\begin{array}{l}\text { Attributes linked to communication strategy, marketing, } \\
\text { merchandising, marketing campaigns }\end{array}$ & $\begin{array}{l}\text { Information/ } \\
\text { Interaction }\end{array}$ & 5 \\
\hline $\begin{array}{l}\text { Attributes linked to sales strategy, customer attraction, offers, } \\
\text { promotional actions (e.g., weekly offers). }\end{array}$ & $\begin{array}{l}\text { Products / } \\
\text { Informação }\end{array}$ & 7 \\
\hline $\begin{array}{l}\text { Attributes linked to identifying, perceiving, meeting customer } \\
\text { needs, knowing the customer, and generating value. }\end{array}$ & $\begin{array}{l}\text { Information/ } \\
\text { Interaction }\end{array}$ & 8 \\
\hline $\begin{array}{l}\text { Attributes linked to business management, costs, profitability, } \\
\text { average tick, potential customers, price research, and lean } \\
\text { management. }\end{array}$ & $\begin{array}{l}\text { Ownership/ } \\
\text { Possession }\end{array}$ & 7 \\
\hline $\begin{array}{l}\text { Attributes linked actions with focus on sustainability, environment } \\
\text { and social responsibility (e.g., social institutions). }\end{array}$ & $\begin{array}{l}\text { Information/ } \\
\text { Interaction }\end{array}$ & 4 \\
\hline $\begin{array}{l}\text { Attributes linked to competence management and organizational } \\
\text { learning. }\end{array}$ & $\begin{array}{l}\text { Ownership/ } \\
\text { Possession }\end{array}$ & 1 \\
\hline \multicolumn{3}{|l|}{ Supermarket operational management } \\
\hline $\begin{array}{l}\text { Attributes linked layout and exposure and definition of sections } \\
\text { and gondolas and management of losses. }\end{array}$ & Environment & 2 \\
\hline $\begin{array}{l}\text { Attributes linked to custom, customized marketing and marketing } \\
\text { actions one to one. }\end{array}$ & $\begin{array}{l}\text { Information/ } \\
\text { Interaction }\end{array}$ & 3 \\
\hline
\end{tabular}




\section{(Figure B.1 (continuation))}

VCAM-S VALUE PROPOSITION ACTIVITIES

\begin{tabular}{|c|c|c|}
\hline 6. Value proposition activity "Strategies / processes" & $\begin{array}{l}\text { Source of } \\
\text { value }\end{array}$ & $\begin{array}{l}\text { Number of } \\
\text { occurrences }\end{array}$ \\
\hline $\begin{array}{l}\text { Attributes linked to communication/interaction with the client (e.g." } \\
\text { through social media and whatsapp). }\end{array}$ & $\begin{array}{l}\text { Information/ } \\
\text { Interaction }\end{array}$ & 3 \\
\hline $\begin{array}{l}\text { Attributes linked to communication and dissemination (e.g., through } \\
\text { radio, billboards, pamphlets, social tabloids, and whatsapp). }\end{array}$ & $\begin{array}{l}\text { Information/ } \\
\text { Interaction }\end{array}$ & 2 \\
\hline $\begin{array}{l}\text { Attributes linked to the implementation of new technologies (e.g." } \\
\text { electronic tags, selfcheckout machines). }\end{array}$ & Environment & 1 \\
\hline $\begin{array}{l}\text { Operational management of processes (e.g., manufacturing process } \\
\text { of rotisserie products, bakery). }\end{array}$ & Products & 1 \\
\hline Providing attributes linked to efficient logistics. & $\begin{array}{l}\text { Ownership/ } \\
\text { Possession }\end{array}$ & 1 \\
\hline Total occurrences & & 52 \\
\hline 7. Value Proposition Activity "Channels of Distribution" & $\begin{array}{l}\text { Source of } \\
\text { value }\end{array}$ & $\begin{array}{l}\text { Number of } \\
\text { occurrences }\end{array}$ \\
\hline \multicolumn{3}{|l|}{ Supply of direct distribution channels } \\
\hline $\begin{array}{l}\text { Provide different channels of direct distribution (e.g., own virtual } \\
\text { store). }\end{array}$ & $\begin{array}{l}\text { Ownership/ } \\
\text { Possession }\end{array}$ & 5 \\
\hline Provide physical store and virtual store integration. & $\begin{array}{l}\text { Ownership/ } \\
\text { Possession }\end{array}$ & 2 \\
\hline $\begin{array}{l}\text { Provide combination of direct and indirect distribution channels } \\
\text { (omnichannel). }\end{array}$ & $\begin{array}{l}\text { Ownership/ } \\
\text { Possession }\end{array}$ & 1 \\
\hline Total occurrences & & 8 \\
\hline 8. Value Proposition Activity "Communication" & $\begin{array}{c}\text { Source of } \\
\text { value }\end{array}$ & $\begin{array}{l}\text { Number of } \\
\text { occurrences }\end{array}$ \\
\hline \multicolumn{3}{|l|}{ Provide advertisement } \\
\hline Custom advertising, one-to-one marketing. & Information & 2 \\
\hline \multicolumn{3}{|l|}{ Provide sales promotion } \\
\hline Provide benefits (e.g., buy and win shares) & $\begin{array}{l}\text { Information/ } \\
\text { Interaction }\end{array}$ & 1 \\
\hline \multirow[t]{2}{*}{ Provide promotional environment, weekly, monthly deals } & Environment & 6 \\
\hline & & (continue) \\
\hline
\end{tabular}




\section{(Figure B.1 (conclusion))}

VCAM-S VALUE PROPOSITION ACTIVITIES

\begin{tabular}{|c|c|c|}
\hline 8. Value Proposition Activity “Communication" & $\begin{array}{l}\text { Source of } \\
\text { value }\end{array}$ & $\begin{array}{l}\text { Number of } \\
\text { occurrences }\end{array}$ \\
\hline \multicolumn{3}{|l|}{ Provide direct marketing } \\
\hline $\begin{array}{l}\text { Personalized advertising, merchandising, marketing campaigns, sales } \\
\text { strategies }\end{array}$ & Information & 3 \\
\hline \multicolumn{3}{|l|}{ Communicate offers, deals } \\
\hline $\begin{array}{l}\text { Communicate offers through traditional advertisements (radio, } \\
\text { tabloids, pamphlets, billboard, TV) }\end{array}$ & Information & 4 \\
\hline $\begin{array}{l}\text { Communicate offers through digital advertisements (Facebook and } \\
\text { Whatsapp) }\end{array}$ & $\begin{array}{l}\text { Information/ } \\
\text { Interaction }\end{array}$ & 1 \\
\hline Provide interaction through social media, Whatsapp, omnichannel. & $\begin{array}{l}\text { Information/ } \\
\text { Interaction }\end{array}$ & 5 \\
\hline \multicolumn{3}{|l|}{ Communicate the brand through public relations } \\
\hline $\begin{array}{l}\text { Support activities and engagement in social responsibility actions } \\
\text { (to promote the brand) }\end{array}$ & $\begin{array}{l}\text { Information/ } \\
\text { Interaction }\end{array}$ & 1 \\
\hline \multicolumn{3}{|l|}{ Communicate the brand through direct marketing } \\
\hline $\begin{array}{l}\text { Communicate the brand through direct marketing with a focus on } \\
\text { generating brand recall. }\end{array}$ & Information & 3 \\
\hline Total occurrences & & 26 \\
\hline
\end{tabular}

Source: Elaborated by the authors. 


\section{) Arrtor Nore}

Paulo R. Condi, Escola de Administração e Negócios, Universidade Federal de Mato Grosso do Sul (UFMS); Dario de O. Lima-Filho, Escola de Administração e Negócios, UFMS; Caroline P. S. Finocchio, Escola de Administração e Negócios, UFMS; Filipe Quevedo-Silva, Programa de Pós-Graduação em Administração, Universidade Nove de Julho.

Paulo R. Condi is now a Professor at Universidade Anhanguera; Dario de O. Lima-Filho, Caroline P. S. Finocchio and Filipe Quevedo-Silva are now Professors at Universidade Federal de Mato Grosso do Sul (UFMS).

Correspondence concerning this article should be addressed to Caroline P. S. Finocchio, Avenida Senador Filinto Müler, 919, Vila Ipiranga, Campo Grandem, Mato Grosso do Sul, Brazil, CEP 79070-900.

E-mail: caroline.spanhol@ufms.br

\section{EDITORIAL BOARD}

Editor-in-chief

Silvio Popadiuk

Associated Editor

Rafael Barreiros Porto

(D) https://orcid.org/0000-0003-2210-7098

Technical Support

Vitória Batista Santos Silva
EDITORIAL PRODUCTION

Publishing Coordination

Irina Migliari

Language Editor

Daniel Leão

Editorial Trainee

Maria Luiza Vanz

Layout Designer

Emap

Copyeditor

Irina Migliari

Graphic Designer

Libro 